\title{
Purification of an L-amino acid oxidase from Bungarus caeruleus (Indian krait) venom
}

\section{More SS (1), Kiran KM (2) Veena SM (2), Gadag JR (2)}

(1) Department of Biochemistry, Center for Postgraduate Studies, Jain University, Bangalore, Karnataka, India; (2) Department of Biochemistry, Karnatak University, Dharwad, Karnataka, India.

ABSTRACT: Snake venoms are rich in enzymes such as phospholipase $A_{2}$, proteolytic enzymes, hyaluronidases and phosphodiesterases, which are well characterized. However, L-amino acid oxidase (LAO EC.1.4.3.2) from snake venoms has not been extensively studied. A novel L-amino acid oxidase from Bungarus caeruleus venom was purified to homogeneity using a combination of ion-exchange by DEAE-cellulose chromatography and gel filtration on Sephadex® G-100 column. The purified monomer of LAO showed a molecular mass of $55 \pm 1 \mathrm{kDa}$ estimated by SDS-PAGE. The specific activity of purified LAO was $6,230 \pm 178 \mathrm{U} / \mathrm{min} / \mathrm{mg}$, versus $230 \pm 3.0 \mathrm{U} / \mathrm{min} / \mathrm{mg}$ for the whole desiccated venom, suggesting a 27 -fold purification with a $25 \%$ yield. Optimal $\mathrm{pH}$ and temperature for maximum purified enzyme activity were 6.5 and $37^{\circ} \mathrm{C}$, respectively. Platelet aggregation studies show that purified LAO inhibited ADP-induced platelet aggregation dose-dependently at 0.01 to $0.1 \mu \mathrm{M}$ with $50 \%$ inhibitory concentration $\left(\mathrm{IC}_{50}\right)$ of $0.04 \mu \mathrm{M}$, whereas at a $0.08 \mu \mathrm{M}$ concentration it did not induce appreciable aggregation on normal platelet-rich plasma (PRP). The purified protein catalyzed oxidative deamination of L-amino acids while the most specific substrate was L-leucine. The purified LAO oxidizes only L-forms, but not Dforms of amino acids, to produce $\mathrm{H}_{2} \mathrm{O}_{2}$. The enzyme is important for the purification and determination of certain amino acids and for the preparation of $\alpha$-keto acids.

KEY WORDS: L-amino acid oxidase, Bungarus caeruleus, platelet aggregation.

CONFLICTS OF INTEREST: There is no conflict.

\section{CORRESPONDENCE TO:}

SUNIL S. MORE, Department of Biochemistry, Jain University, $18 / 3,9^{\text {th }}$ Main Jayanagar $3^{\text {rd }}$ Block Bangalore, 560011 Karnataka, India. Phone: 08041210694. Fax: 080 41210692. Email: sunilacr@yahoo.co.in. 


\section{INTRODUCTION}

L-amino acid oxidase (LAO, EC1.4.3.2) is a flavoenzyme that catalyzes the stereospecific oxidative deamination of an L-amino acid and act as substrate to an $\alpha$ keto acid along with the production of ammonia and hydrogen peroxide $\left(\mathrm{H}_{2} \mathrm{O}_{2}\right)$. There was complete decomposition of L-amino acids like leucine, isoleucine, norleucine, $\alpha$ amino butyric acid, phenylalanine, tyrosine, tryptophan norvaline, methionine, histidine citrulline, serine, threonine, aspartic acid, glutaric acid, lysine and ornithine by LAO.

The enzyme is widely distributed in many different organisms, including the venoms of a variety of snake species. Snake venom components have been widely used in medicine as diagnostic or therapeutic tools and also as models for studying processes in cell biology. The demonstrated presence of LAOs in mouse milk suggests a possible function of anti-bacterial role in the mammary gland (1). The enzyme has been isolated from different venoms and its effects on platelets, induction of apoptosis, hemorrhagic and antibacterial effects vary widely (2-9).

Venom LAOs are usually homodimeric FAD-binding glycoproteins with molecular mass from 110 to $150 \mathrm{kDa}(10)$. They share sequence similarity with human monoamine oxidase and with bacterial and fungal LAOs only at the FAD-binding site. In addition, these proteins share significant similarity (more than $30 \%$ identity) with mouse interleukin 4-induced protein $(1,11)$. Recently, the LAO structure from Calloselasma rhodostoma has been determined by x-ray crystallography (12). The enzyme is structurally a dimer and each subunit consists of three domains: a FADbinding domain, a substrate binding domain, and a helical domain.

Reported biological activities of venom LAOs include apoptosis-inducing activity on various human cell lines, inhibition or induction of platelet aggregation and antibacterial effect $(2,3,7,13$,$) . These activities are mainly associated with the$ production of highly localized concentrations of $\mathrm{H}_{2} \mathrm{O}_{2}$, since catalase, a $\mathrm{H}_{2} \mathrm{O}_{2}$ scavenger, inhibits the biological effects of LAOs as well as those of $\mathrm{H}_{2} \mathrm{O}_{2}$. The present investigation reports the purification and characterization of a novel LAO, designated BCV-LAO, from the venom of Indian krait (Bungarus caeruleus) with respect to its molecular mass and biochemical properties. 


\section{MATERIALS AND METHODS}

\section{Reagents and Chemicals}

Lyophilized Bungarus caeruleus venom was obtained from the Haffkine Institute, Parel, Mumbai, India. Chemicals and column materials, including Sephadex® G-100, were obtained from Pharmacia Biotech (Sweden). DEAE-cellulose, o-dianisidine hydrochloride and horseradish peroxidase were from Sigma Chemicals (USA). All other chemicals and reagents used were of analytic grade from commercial sources. The protein concentration of the final product was determined by a protein assay kit (Bangalore Genei Chemicals, India) with bovine serum albumin as standard.

\section{Purification Procedures}

Two-step purification of L-amino acid oxidase was carried out by the method of Wei et al. (14).

\section{First step: DEAE-cellulose column chromatography}

The crude Bungarus caeruleus snake venom $(100 \mathrm{mg}$ ) dissolved in $5 \mathrm{~mL}$ of $0.05 \mathrm{M}$ Tris- $\mathrm{HCl}$ buffer, $\mathrm{pH} 7.5$, was loaded on a previously equilibrated DEAE-cellulose column $(1.5 \times 18 \mathrm{~cm})$. After washing the column with $500 \mathrm{~mL}$ of $0.05 \mathrm{M}$ Tris-HCL buffer, $\mathrm{pH} 7.5$, the enzyme was eluted using $250 \mathrm{~mL}$ of $0-0.5 \mathrm{M} \mathrm{NaCl}$ linear gradient with a $24 \mathrm{~mL} /$ hour flow rate of $2.0 \mathrm{~mL}$ fractions. The fractions showing LAO activity were pooled, dialyzed and used in the next step.

\section{Second step: Sephadex ${ }^{\circledR}$ G-100 column chromatography}

The dialyzed fractions showing LAO activity were further subjected to gel filtration chromatography on a previously equilibrated Sephadex ${ }^{\circledR}$ G-100 column $(1.5 \times 60$ $\mathrm{cm}$ ). After washing the column with $500 \mathrm{~mL}$ of $0.05 \mathrm{M}$ Tris-HCL buffer, $\mathrm{pH} 7.5$, the protein fractions were eluted at a flow rate of $12 \mathrm{~mL} /$ hour in 1.2- $\mathrm{mL}$ fractions. The fractions showing LAO activity were pooled, dialyzed, lyophilized, stored at $-20^{\circ} \mathrm{C}$ and subsequently used for characterization and confirming their homogeneity.

\section{LAO Activity}

The LAO activity was assayed by measuring the initial rate of hydrogen peroxide production with a coupled peroxidase/dye assay (15). The dye formation was spectrophotometrically measured at $436 \mathrm{~nm}$ and $30^{\circ} \mathrm{C}$. The assay mixture, with $\mathrm{pH}$ 
7.6, contained $10 \mathrm{mM}$ L-leucine, $0.2 \mathrm{M}$ Tris-HCl buffer, $0.2 \mathrm{mg} / \mathrm{mL}$ o-dianisidine hydrochloride, $100 \mathrm{U} / \mathrm{mL}$ horseradish peroxidase and LAO in limiting amounts. To test the enzymatic specificity of the purified LAO, L-leucine was replaced with other L-amino acids under identical assay conditions. The amount of purified LAO in the reaction mixture was $4.0 \mathrm{\mu g}$. One unit $(U)$ is defined as the amount of enzyme that catalyzes the formation of $1 \mu \mathrm{mol} \mathrm{H}_{2} \mathrm{O}_{2}$ per minute. Protein concentration was determined by the dye binding method of Bradford (16) using bovine serum albumin as standard.

\section{Stability Studies}

To investigate the effects of the purified enzyme under freezing conditions in PBS $\left(\mathrm{pH}\right.$ 7.6), it was stored for two months at $-80^{\circ} \mathrm{C}$. The treated enzyme was incubated for 30 minutes at $30^{\circ} \mathrm{C}$. LAO activity was determined as described by Bergmeyer (17).

\section{$\mathrm{K}_{\mathrm{M}}$ and $\mathrm{V}_{\max }$ Determinations}

For the determination of $\mathrm{K}_{\mathrm{M}}$ and $\mathrm{V}_{\max }$, the enzyme concentration was adjusted to catalyze $50 \%$ of $1 \mu \mathrm{mol} \mathrm{H}_{2} \mathrm{O}_{2}$ per minute with $10 \mathrm{mM}$ L-leucine as substrate under optimum conditions $\left(30^{\circ} \mathrm{C}\right.$ and $\left.\mathrm{pH} 7.6\right)$. The activity was expressed as the formation of one micromole of $\mathrm{H}_{2} \mathrm{O}_{2}$ per minute and all the assays were performed in triplicate

\section{Native Polyacrylamide Gel Electrophoresis (PAGE) of Purified L-amino Acid Oxidase}

Homogeneity of the purified enzyme was tested by PAGE according to the method of Davis (18).

\section{Purity Criterion and Molecular Mass Determination by Sodium Dodecyl Sulfate Polyacrylamide Gel Electrophoresis (SDS-PAGE)}

Molecular mass of the purified enzyme was determined by SDS-PAGE according to Laemmli (19), using standard molecular mass markers. 


\section{Molecular Mass Determination by Gel Filtration Chromatography}

The molecular mass of the purified L-amino acid oxidase was estimated by gel filtration chromatography according to Andrews (20) on calibrated columns of Sephadex® G-75, using 0.05 M Tris-HCl buffer ( $\mathrm{pH} 8.5)$.

Sephadex® G-75 was suspended in 0.05 M Tris-HCl buffer $(\mathrm{pH} \mathrm{8.5)} \mathrm{containing} 100$ $\mathrm{mM} \mathrm{NaCl}$ and allowed to swell for 24 hours. The fine particles were removed by decanting the supernatant whereas the swollen gel was deaerated by leaving it overnight in a vacuum desiccator. The gel was packed into a column $(1.5 \times 60 \mathrm{~cm})-$ equilibrated with the same buffer - and the flow rate was kept at $12 \mathrm{~mL} / \mathrm{hour}$ using a peristaltic pump.

Void volume $\left(\mathrm{V}_{\mathrm{o}}\right)$ of the column was determined through blue dextran $(2 \mathrm{mg} / \mathrm{mL}$ in equilibration buffer containing $3 \%$ sucrose). The column was calibrated with standard molecular mass markers. Each standard protein $(2 \mathrm{mg} / \mathrm{mL})$ in the buffer containing $3 \%$ sucrose was layered on the gel. The elution was carried out with the same buffer at a constant flow rate $(12 \mathrm{~mL} /$ hour $)$. Three-milliliter fractions were collected on a fraction collector (FRAC-100®, Pharmacia, Sweden), while the protein elution was monitored by determining the absorbance at $280 \mathrm{~nm}$ using a Hitachi 150-20尺 spectrophotometer (Japan).

The total eluent volume up to the fraction presenting maximum absorbance was considered the eluent volume of the protein $\left(V_{e}\right)$. Elution volumes of different standard proteins of known molecular mass were determined under similar conditions. The elution volume for the purified L-amino acid oxidase was also determined.

A calibration curve was obtained by plotting values of $V_{e} / V_{o}$ against their respective logarithmic molecular masses. Lysozyme, chymotrypsinogen A, carbonic anhydrase, ovalbumin and bovine serum albumin were employed as standard proteins to obtain the calibration curve. From this curve, the molecular mass of purified L-amino acid oxidase was estimated

\section{Platelet Aggregation Studies}

Platelet aggregation was assessed according to Toyama et al. (21). Venous blood was collected, with informed consent, from healthy volunteers who denied taking any medication in the previous 14 days. Samples were collected by a two-syringe technique using sterile syringes, and immediately transferred into polypropylene 
tubes containing $1 / 10^{\text {th }}$ of the final volume of $3.8 \%$ trisodium citrate. Platelet-rich plasma (PRP) was prepared by centrifugation of citrated blood at $200 \mathrm{xg}$ for ten minutes. Aggregation experiments were performed in triplicate at various concentrations of LAO.

\section{Statistical Analysis}

The results were expressed as the mean \pm SEM. Data were evaluated by the analysis of variance (ANOVA) test. The significance level was set at $p<0.05$.

\section{RESULTS}

A two-step protocol was standardized for LAO purification. The first step involved DEAE-cellulose ion exchange chromatography that had fractionated crude Bungarus caeruleus venom in three peaks with significant protein concentrations. Fractions 2543 showed the highest LAO activity (Figure 1).

The second step involved gel filtration chromatography of lyophilized peak II obtained in step one, which was further resolved into three peaks with significant protein concentrations. LAO activity was observed at peak II (fractions 38-51) (Figure 2). The enzyme was purified 27 -fold with a yield of $25.8 \%$, having a specific activity of 6,230 $\pm 114 \mathrm{U} / \mathrm{min} / \mathrm{mg}$ of protein (Table 1 ).

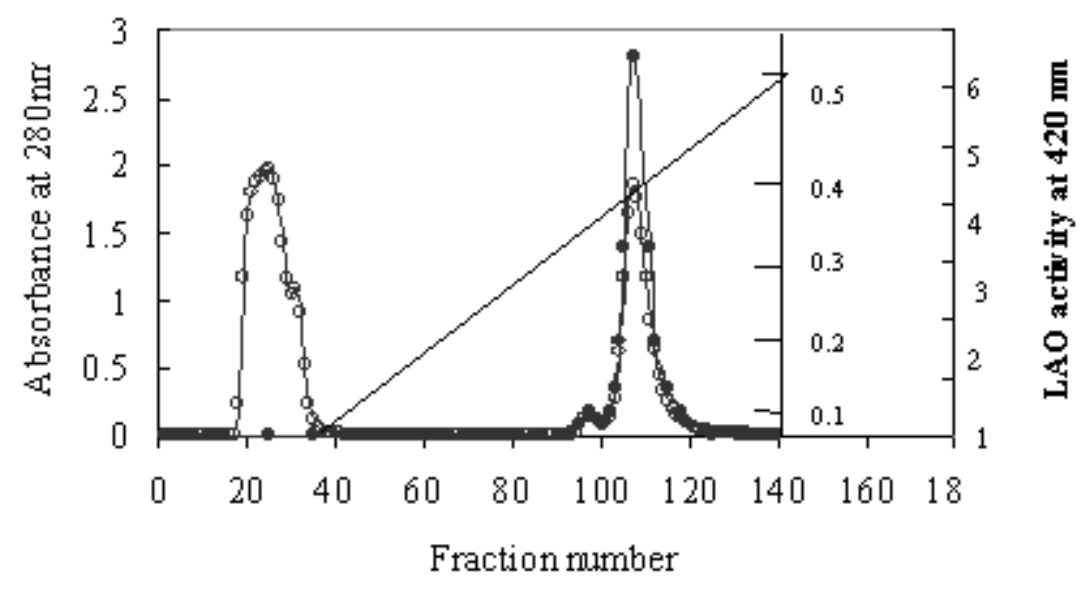

Figure 1. Crude Bungarus caeruleus snake venom (100 mg) dissolved in $5 \mathrm{~mL}$ of Tris- $\mathrm{HCl}$ buffer, $\mathrm{pH} 7.5$, was loaded on a previously equilibrated DEAE-cellulose column $(1.5 \times 18 \mathrm{~cm})$ after washing the column with $500 \mathrm{~mL}$ of $0.05 \mathrm{M}$ Tris-HCL buffer (pH 7.5). The enzyme was eluted using $250 \mathrm{~mL} 0-0.5 \mathrm{M} \mathrm{NaCl}$ linear gradient with a $24 \mathrm{~mL} /$ hour flow rate in $2.0 \mathrm{~mL}$-fractions. The fractions showing LAO activity were pooled, dialyzed and used in the next step. 


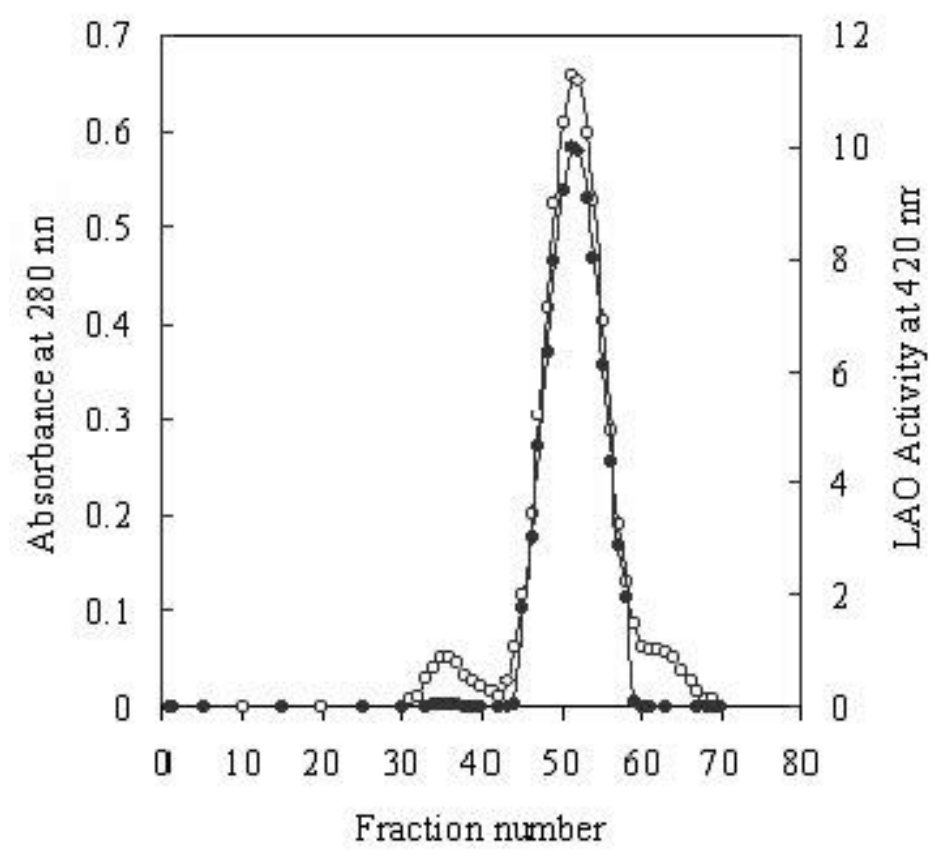

Figure 2. The dialyzed fractions (25-37) showing LAO activity were further subjected to gel filtration chromatography on a previously equilibrated Sephadex ${ }^{\circledR}$ G-100 column $(1.5 \times 60 \mathrm{~cm})$ after washing the column with $500 \mathrm{~mL}$ of $0.05 \mathrm{M}$ Tris- $\mathrm{HCl}$ buffer $(\mathrm{pH} 7.5)$. The protein fractions were eluted at a flow rate of $12 \mathrm{~mL} / \mathrm{hour}$ in $1.2-\mathrm{mL}$ fractions.

Table 1. Summary of L-amino acid oxidase purification from Bungarus caeruleus venom

\begin{tabular}{|c|c|c|c|c|c|c|}
\hline $\begin{array}{c}\text { Sample } \\
\text { number }\end{array}$ & Steps & $\begin{array}{c}\text { Protein } \\
\text { content } \\
(\mathbf{m g})\end{array}$ & $\begin{array}{c}\text { Total } \\
\text { activity } \\
\mathbf{1} \mathbf{U}=1 \\
\boldsymbol{\mu m o l e} \\
\mathrm{H}_{2} \mathrm{O}_{2} / \mathbf{m i n}\end{array}$ & $\begin{array}{c}\text { Specific } \\
\text { activity } \\
\text { U/mg }\end{array}$ & $\begin{array}{c}\text { Fold } \\
\text { purification }\end{array}$ & $\begin{array}{c}\% \\
\text { yield }\end{array}$ \\
\hline 1 & Crude venom & 100 & $2500 \mathrm{U}$ & 230 & 1 & 100 \\
\hline 2 & $\begin{array}{c}\text { DEAE } \\
\text { chromatography }\end{array}$ & 15 & $1350 \mathrm{U}$ & 2100 & 9.1 & 54 \\
\hline 3 & $\begin{array}{c}\text { Sephadex® G- } \\
100\end{array}$ & 4.9 & $647 \mathrm{U}$ & 6230 & 27.1 & 25.8 \\
\hline
\end{tabular}




\section{Purity Criterion and Molecular Mass Determination}

The purified L-amino acid oxidase enzyme, when subjected to native PAGE, showed a single band, indicating its homogeneity. The LAO molecular mass was estimated by SDS-PAGE (Figure 3) and by gel filtration on Sephadex® G-100 using standard protein molecular mass markers and was found to be $55.0 \pm 1.0 \mathrm{kDa}$.

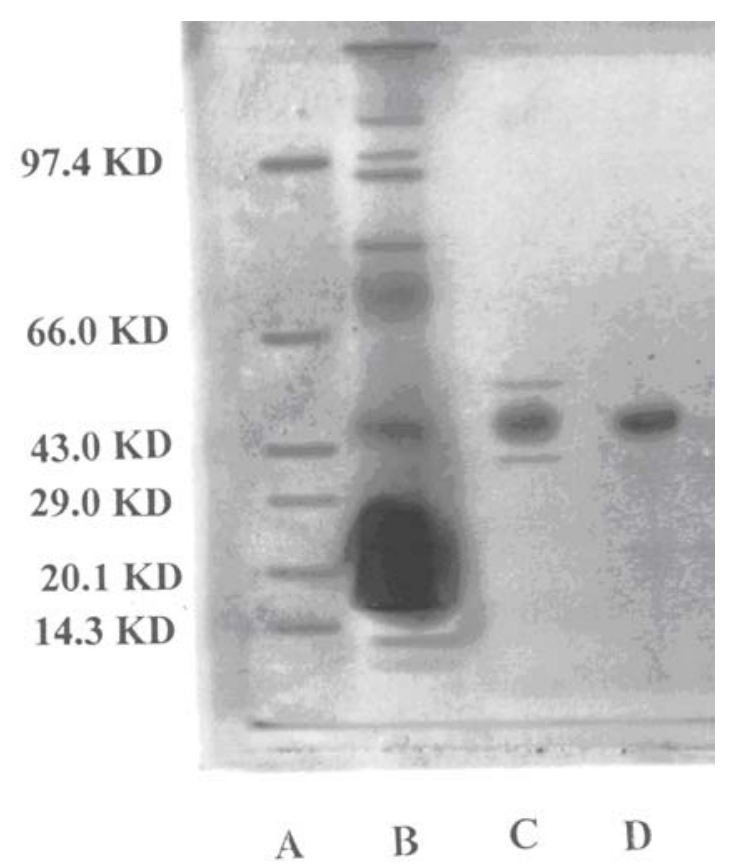

Figure 3. SDS-PAGE of the purified Bungarus caeruleus L-amino acid oxidase. Lane A: molecular weight markers; lane B: crude Bungarus caeruleus venom; lane C: purified enzyme after DEAE-cellulose column; lane D: purified enzyme after Sephadex® G-100 column chromatography. Marker proteins used for calibration: (a) phosphorylase b (97,400); (b) bovine serum albumin (66,000); (c) ovalbumin (43,000); (d) carbonic anhydrase (29,000); (e) soyabean trypsin inhibitor $(20,100)$; (f) lysozyme $(14,300)$ standard proteins from lane $A(h)$ purified L-amino acid oxidase from lane D.

\section{Enzyme Stability}

The purified enzyme was found to be stable at -20 or $-80^{\circ} \mathrm{C}$ for two months and at $4^{\circ} \mathrm{C}$ for one month, whereas its activity was enhanced by the addition of $10 \mu \mathrm{M}$ FAD (data not shown). The enzyme activity remained unaffected between 30 and $40^{\circ} \mathrm{C}$. Freezing and thawing did not affect the enzyme activity as long as it was stored at a $\mathrm{pH}$ from 6.0 to 7.0 . 


\section{LAO Substrate Specificity}

The purified LAO presents broad substrate specificity when tested for a wide range of amino acids. It revealed high specificity for L-Glu, L-Leu, L-Met, L-Ile, L-Phe and LArg; whereas it presented moderate specific activity for L-His, L-Trp, L-Asn, L-Gln, LLys and L-Asp; it showed no specific activity for L-Thr, L-Ser, L-Pro, L-Val and L-Tyr (Table 2).

Table 2. Substrate specificity of L-amino acid oxidase

\begin{tabular}{|c|c|}
\hline L-amino acid & Specific activity (U/mg) \\
\hline L-Glu & 25.9 \\
L-Leu & 33.6 \\
L- Met & 30.5 \\
L-Ile & 22.5 \\
L-Phe & 21.5 \\
L-His & 12.7 \\
L-Gly & 0.00 \\
L-Trp & 10.3 \\
L-Arg & 18.9 \\
L-Asn & 4.12 \\
L-Glu & 3.45 \\
L-Gln & 2.35 \\
L-Lys & 0.95 \\
L-Asp & 0.94 \\
L-Cys & 0.33 \\
L-Thr & 0.0 \\
L-Ser & 0.0 \\
L-Pro & 0.0 \\
L-Val & 0.0 \\
L-Tyr & 0.0 \\
\hline
\end{tabular}

Note: the reaction mixture consisted of $1.0 \mu \mathrm{g}$ purified LAO, $20 \mu \mathrm{g}$ peroxidase, $65 \mu \mathrm{g}$ o-dianisidine and $2 \mathrm{mM}$ of L-amino acid as substrate in $1 \mathrm{~mL}$ of $0.1 \mathrm{M}$ Tris- $\mathrm{HCl}$ buffer ( $\mathrm{pH}$ 8.5); the experiments were conducted at $25^{\circ} \mathrm{C}$. 


\section{Temperature and pH Effects on Enzyme Activity}

The optimum $\mathrm{pH}$ for L-amino acid oxidase activity is 4.5 while the best temperature is $37^{\circ} \mathrm{C}$.

\section{Determination of $\mathrm{K}_{\mathrm{m}}$ and $\mathrm{V}_{\max }$}

The effect of varying concentrations of L-leucine at the initial LAO velocity showed a typical hyperbolic saturation curve. The $\mathrm{K}_{m}$ value for $\mathrm{L}$-amino acid oxidase, as determined in the Lineweaver-Burk plot, was found to be $48.61 \mu \mathrm{M} / \mathrm{mL}$.

\section{Platelet Aggregation}

The LAO, preincubated with normal PRP for two minutes, inhibited ADP-induced platelet aggregation dose-dependently at 0.01 to $0.1 \mu \mathrm{M}$ with $\mathrm{IC}_{50}$ of $0.04 \mu \mathrm{M}$. This inhibition was completely lost when PRP and LAO were incubated with catalase $(0.3$ $\mathrm{mg} / \mathrm{mL}$ ) before adding ADP (Figure 4). LAO at a concentration of $0.08 \mu \mathrm{M}$ did not induce appreciable aggregation in normal PRP (Figure 5).

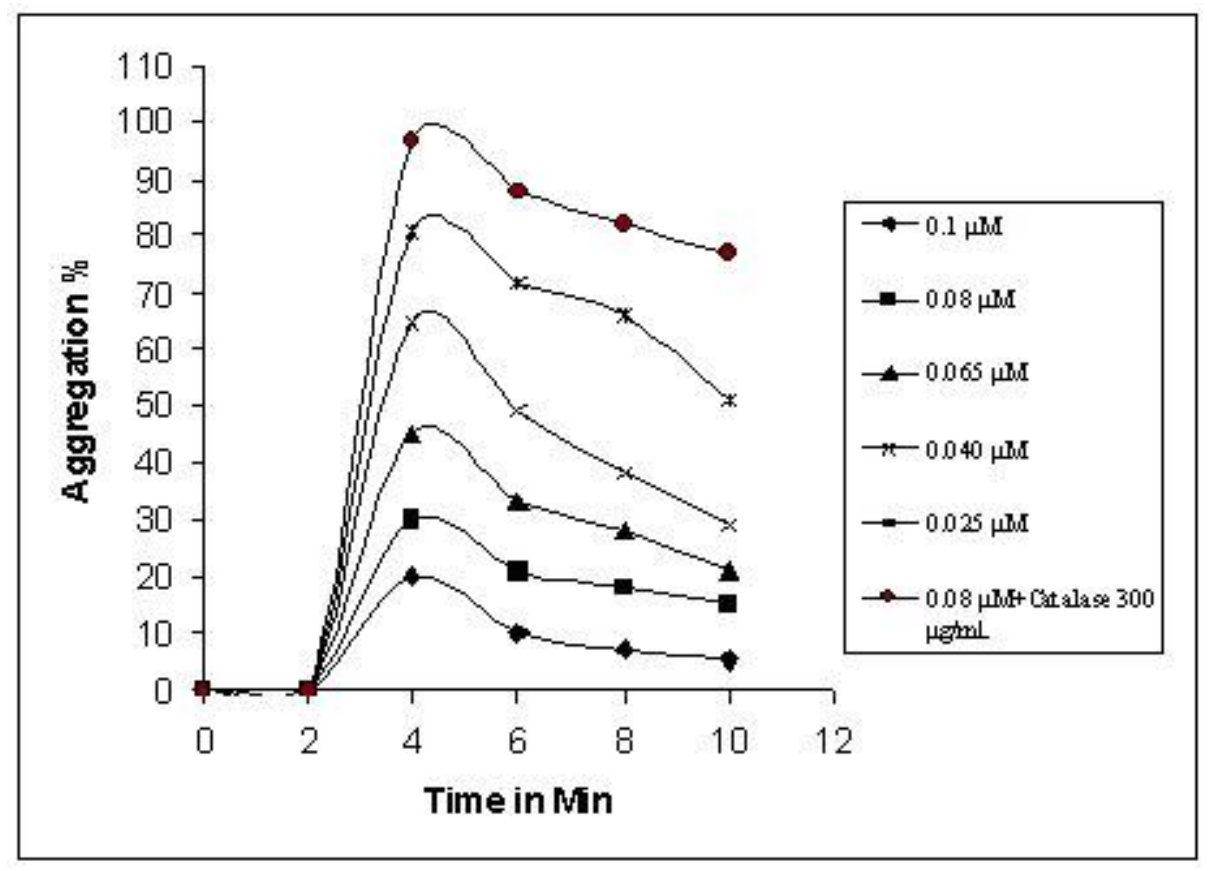

Figure 4. Effects of LAO on human platelet aggregation in PRP. Platelet aggregometer values of ADP-induced $(10 \mu \mathrm{M})$ human platelet aggregation inhibited by LAO $(0.025$ to $0.1 \mu \mathrm{M})$. 


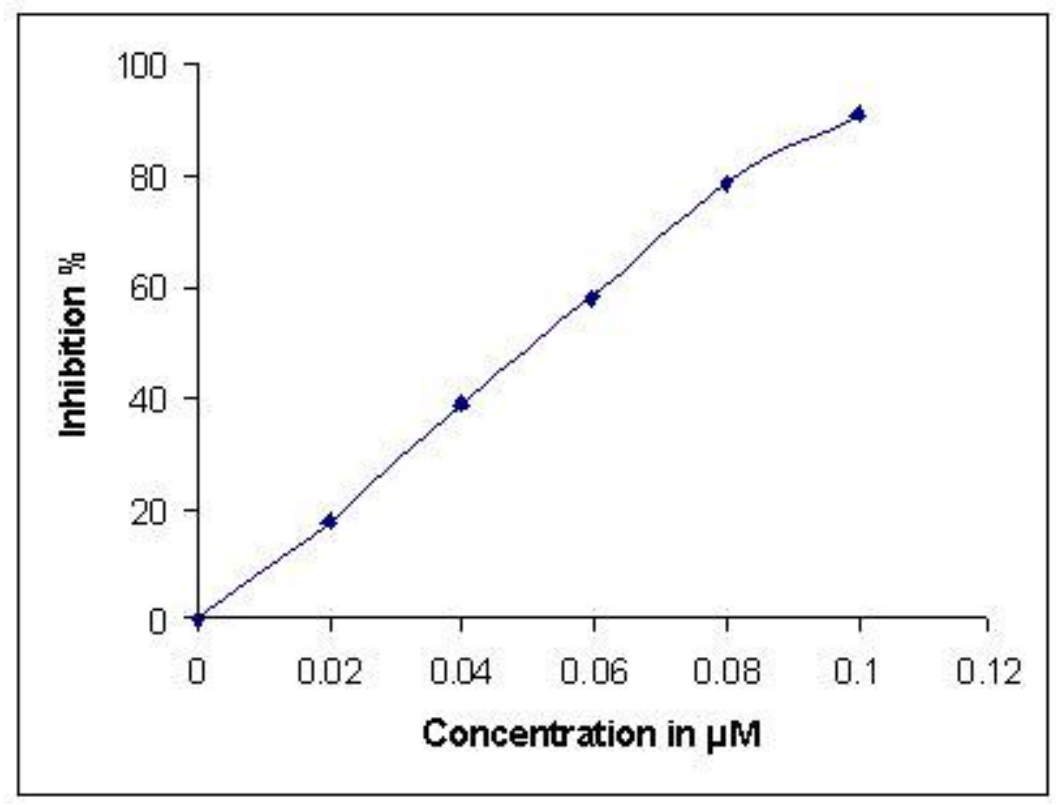

Figure 5. LAO concentration-dependent inhibition on ADP-induced human platelet aggregation studies. Results are shown as mean $\pm(n=3)$.

\section{DISCUSSION}

Snake venoms are commonly used as tools for the development of new therapeutic approaches since these substances present a broad range of pharmacological activities $(22,23)$

In the present investigation, the Bungarus caeruleus venom L-amino acid oxidase was purified and its molecular mass characterized. The purified LAO from $B$. caeruleus Indian krait venom showed a single band of $55 \pm 1 \mathrm{kDa}$. This corroborates a previous report by Tan and Swaminathan (24), in which the enzyme had a molecular mass of $57.4 \mathrm{kDa}$, as determined by SDS-PAGE. The crude venom was fractionated and the active component purified. The biochemical properties of the purified enzyme were consistent with snake L-amino acid oxidases found by other authors (25).

The molecular mass and structure of LAO, found in our experiments, were also described in numerous L-amino acid oxidases, ranging from $50 \mathrm{kDa}$ in the monomeric form to $150 \mathrm{kDa}$ as a dimer (26-28). The presence of multiple isoforms of this enzyme in some snake venoms was also reported $(29,30)$. The purified enzyme in the present study was called BCV-LAO. By the enzymatic assay, the LAO presented 28 -fold more activity than crude venom, suggesting a significant degree of 
purification. LAO catalyzes the oxidative deamination of L-amino acids to produce the corresponding $\beta$-ketoacid, hydrogen peroxide and ammonia $(31,32)$.

The optimum $\mathrm{pH}$ and temperature for isolating LAO in $B$. caeruleus were, respectively, 6.5 and $37^{\circ} \mathrm{C}$, consistent with previous findings for other snake L-amino acid oxidases (33). Before the 1990s, snake venom LAOs were mainly utilized to identify optical isomers of amino acids and to prepare of a-keto acids $(34,35)$. Usually, the oxidizing activity is determined using L-Leu as substrate. In the case of viperid venoms, hydrophobic amino acids (including L-Leu) are the best substrates for LAO $(36,37)$. The substrate specificity of $B$. caeruleus LAO is in accordance with other studied snake venom LAOs. Hydrophobic amino acids (L-Phe, L-Met, L-Leu and L-Ile) are the best substrates, while L-Ser, Gly, L-Lys, LThr and L-Pro are not oxidized.

The catalytic differences may be explained by differences in side chain binding sites responsible for the enzyme substrate specificity. The presence of three to four hydrophobic subsites and two amino-binding subsites have been hypothesized for the enzymes isolated from the elapid venom of Naja naja kaouthia (28) as well as for the C. rhodostoma LAO (32).

Several LAOs inhibit whereas others induce platelet aggregation (in the same concentration range) by some supplementary mechanisms in addition to $\mathrm{H}_{2} \mathrm{O}_{2}$ release (38). One reason for such inhibition may be reduced ADP binding in platelets exposed to $\mathrm{H}_{2} \mathrm{O}_{2}$ (38). The inhibitory activity might also be explained by the interference of peroxide in the interaction between activated platelet integrin GPIIb/IIla and fibrinogen. The induction of aggregation is connected with peroxide formation and subsequent tromboxane $A_{2}$ synthesis requiring $\mathrm{Ca}^{2+}$, but is independent of ADP release (1). Snake venom LAOs are interesting multifunctional enzymes owing their effects, at least partly, to hydrogen peroxide release in the oxidation process. Ascertainment of the exact mechanisms of pharmacological activities require further studies. 


\section{REFERENCES}

1. Du XY, Clemetson KJ. Snake venom L-amino acid oxidases. Toxicon. 2002;40(2):659-65.

2. Suhr SM, Kim DS. Identification of the snake venom substance that induces apoptosis. Biochem Biophys Res Commun. 1996;224(1):134-9.

3. Stiles BG, Sexton FW, Weinstein SA. Antibacterial effects of different snake venoms: purification and characterization of antibacterial proteins from Pseudechis australis (Australian king brown or mulga snake) venom. Toxicon. 1991;29(9):112941.

4. Sun LK, Yoshii Y, Hyodo A, Tsurushima H, Saito A, Harakuni T, Li YP, Kariya K, Nozaki M, Morine N. Apoptotic effect in the glioma cells induced by specific protein extracted from Okinawa habu (Trimeresurus flavoviridis) venom in relation to oxidative stress. Toxicol In Vitro. 2003;17(2):169-77.

5. Stabeli RG, Marcussi S, Carlos GB, Pietro RCLR, Selistre-de-Araújo HS, Giglio JR, Oliveira EB, Soares AM. Platelet aggregation and antibacterial effects of an Lamino acid oxidase purified from Bothrops alternatus snake venom. Bioorg Med Chem. 2004;12(11):2881-6.

6. Tempone AG, Andrade HF Jr, Spencer PJ, Lourenço CO, Rogero JR, Nascimento N. Bothrops moojeni venom kills Leishmania spp. with hydrogen peroxide generated by its L-amino acid oxidase. Biochem Biophys Res Commun. 2001;280(3):620-4.

7. Takatsuka H, Sakurai Y, Yoshioka A, Kokubo T, Usami Y, Suzuki M, Matsui T, Titani K, Yagi H, Matsumoto M, Fujimura Y. Molecular characterization of L-amino acid oxidase from Agkistrodon halys blomhoffii with special reference to platelet aggregation. Biochim Biophys Acta. 2001;1544(1-2):267-77.

8. Zhang YI, Wang JH, Lee WH, Wang Q, Liu H, Zheng YT, Zhang Y. Molecular characterization of Trimeresurus stejnegeri venom L-amino acid oxidase with potential anti-HIV activity. Biochem Biophys Res Commun. 2003;309(3):598-604.

9. Ali SA, Stoeva S, Abbasi A, Alam JM, Kayed R, Faigle M, Neumeister B, Voelter W. Isolation, structural and functional characterization of an apoptosis-inducing Lamino acid oxidase from leaf-nosed viper (Eristocophis macmahoni) snake venom. Arch Biochem Biophys. 2000;384(2):216-26.

10. Sun Y, Nonobe E, Kobayashi Y, Kuraishi T, Aoki F, Yamamoto K, Sakai S. Characterization and expression of L-amino acid oxidase of mouse milk. J Biol Chem. 2002;277(21):19080-6. 
11. Raibekas AA, Massey V. Primary structure of the snake venom L-amino acid oxidase shows high homology with the mouse B cell interleukin 4-induced Fig1 protein. Biochem Biophys Res Commun. 1998;248(3):476-8.

12. Pawelek PD, Cheah J, Coulombe R, Macheroux P, Ghisla S, Vrielink A. The structure of L-amino acid oxidase reveals the substrate trajectory into an enantiomerically conserved active site. EMBO J. 2000;19(16):4204-15.

13. Torri S, Naito M, Tsuruo T. Apoxin I, a novel apoptosis-inducing factor with Lamino acid oxidase activity purified from western diamondback rattlesnake venom. J Biol Chem. 1997;272(14):9539-42.

14. Wei JF, Wei Q, Lu QM, Tai H, Jin Y, Wang WY, Xiong YL. Purification, characterization and biological activity of an L-amino acid oxidase from Trimeresurus mucrosquamatus venom. Acta Biochim Biophys Sin. 2003;35(2):219-24.

15. Li ZY, Yu TF, Lian EC. Purification and characterization of L-amino acid oxidase from king cobra (Ophiophagus hannah) venom and its effects on human platelet aggregation. Toxicon. 1994;32(11):1349-58.

16. Bradford MM. A rapid and sensitive method for the quantitation of microgram quantities of protein utilizing the principle of protein-dye binding. Anal Biochem. 1976;72(1-2):248-54.

17. Bergmeyer HU. L-amino acid oxidase. In: Bergmeyer HU, editor. Methods in enzymatic analysis. Weinheim: Verlag Chemie, GmbH; 1983. 2 vols. p. 149-50.

18. Davis BJ. Disc electrophoresis. II. Method and application to human serum proteins. Ann N Y Acad Sci. 1964;121(2):404-27

19. Laemmli UK. Cleavage of structural proteins during the assembly of the head of bacteriophage T4. Nature. 1970;227(5259):680-5.

20. Andrews P. Estimation of the molecular weights of proteins by Sephadex gelfiltration. Biochem J. 1964;91(2):222-33.

21. Toyama MH, Toyama DO, Passero LF, Laurenti MD, Corbett CE, Tomokane TY, Fonseca FV, Antunes E, Joazeiro PP, Beriam LO, Martins MA, Monteiro HS, Fonteles MC. Isolation of a new L-amino acid oxidase from Crotalus durissus cascavella venom. Toxicon. 2006;47(1):47-57.

22. 15. Nathan I, Dvilansky A, Yirmiyahu T, Aharon M, Livne A. Impairment of platelet aggregation by Echis colorata venom mediated by L-amino acid oxidase or $\mathrm{H}_{2} \mathrm{O}_{2}$. Thromb Haemost. 1982;48(3):277-82. 
23. Ahn MY, Lee BM, Kim YS. Characterization and cytotoxicity of L-amino acid oxidase from the venom of king cobra (Ophiophagus hannah). Int J Biochem Cell Biol. 1997;29(6):911-9.

24. Tan NH, Swaminathan S. Purification and properties of L-amino acid oxidase from monocellate cobra (Naja naja kaouthia) venom. Int J Biochem. 1992;24(6):96773.

25. Suhr SM, Kim DS. Comparison of the apoptotic pathways induced by L-amino acid oxidase and hydrogen peroxide. J Biochem. 1999;125(2):305-9.

26. Kamata K, Arai Y, Sakamoto A, Kasuya Y, Samejima Y. Pharmacological action of the phospholipase $A_{2}$ from the venom of Trimeresurus flavoviridis on the smooth muscle of the rat stomach. Life Sci. 1989;44(2):137-42.

27. Chen SZJ, Gopalakrishnakone P, Gwee MCE. Pharmacological effects and pathological changes induced by the venom of Pseudechis australis in isolated skeletal muscle preparations. Toxicon. 1994;32(3):303-15.

28. Tan NH, Saifuddin MN. Substrate specificity of king cobra (Ophiophagus hannah) venom L-amino acid oxidase. Int J Biochem. 1991;23(3):323-7.

29. Ponnudurai G, Chung MC, Tan NH. Purification and properties of the L-amino acid oxidase from Malayan pit viper (Calloselasma rhodostoma) venom. Arch Biochem Biophys. 1994;313(2):373-8.

30. Nakano K, Inamas Y, Hagihara S, Obo F. Isolation and properties of L-amino acid oxidase in habu snake (Trimeresurus flavoviridis) venom. Acta Med Univ Kagoshima. 1972;14:229-39.

31. Shaham N, Bdolah A. L-amino acid oxidase from Vipera palaestinae venom: purification and assay. Com Biochem Physiol. 1973;46(4):691-8.

32. Pessatti ML, Fontana JD, Furtado MFD, Guimarães MF, Zanette LRS, Costa WT, Baron M. Screening of Bothrops snake venoms for L-amino acid oxidase activity. Appl Biochem Biotechnol. 1995;51-52(1):197-210.

33. Wellner D, Meister A. Studies on the mechanism of action of L-amino acid oxidase. J Biol Chem. 1961;236:2357-64.

34. Wellner D, Meister A. Crystalline L-amino acid oxidase of Crotalus adamanteus. J Biol Chem. 1960;235:2013-8.

35. Tan NH. L-amino acid oxidases and lactate dehydrogenases. In: Bailey GS, editor. Enzymes from snake venom. Fort Collins: Alaken Inc.;1998. p. 579-98. 
36. Iwanaga S, Suzuki T. Enzymes in snake venoms. In: Lee CY, editor. Snake venoms. New York: Springer-Verlag, Berlin-Heidelberg; 1979. p. 61-158.

37. Souza DHF, Eugenio LM, Fletcher JE, Jiang MS, Garratt RC, Oliva G, Selistrede-Araujo HS. Isolation and structural characterization of a cytotoxic L-amino acid oxidase from Agkistrodon contortrix laticinctus snake venom: preliminary crystallographic data. Arch Biochem Biophys. 1999;368(2):285-90.

38. Belisario MA, Tafuri S, Di Domenico C, Squillacioti C, Della Morte R, Lucisano A, Staiano N. $\mathrm{H}_{2} \mathrm{O}_{2}$ activity on platelet adhesion to fibrinogen and protein tyrosine phosphorylation. Biochim Biophys Acta. 2000;1495(2):183-93. 